\title{
MULTIDRUG RESISTANT ESCHERICHIA COLI PADA SUMBER AIR MINUM DI KOTA TANGERANG
}

*Aminah, *Jamilatun M.

\begin{abstract}
Abstrak
Multidrug-resistant Escherichia coli (MDR E. coli) telah menjadi perhatian dalam hal kesehatan masyarakat di berbagai negara. Bakteri ini menyebabkan infeksi yang sulit ditangani sehingga dampak buruk yang ditimbulkan bagi kesehatan menjadi luas. Penelitian ini bertujuan untuk menentukan prevalensi dan kerentanan MDR $E$. coli yang diisolasi dari sumber air minum masyarakat yang berada di Kota Tangerang. Penelitian ini dilaksanakan pada bulan Mei - Juni 2015. Desain yang digunakan adalah penelitian eksperimental laboratorium. Populasi dalam penelitian ini adalah seluruh bakteri $E$. coli yang diisolasi dari sumber air minum masyarakat di Kota Tangerang. Semua bakteri yang diisolasi digunakan sebagai sampel. Hasil penelitian menunjukkan bahwa dari 16 sumber air minum masyarakat, enam di antaranya positif mengandung E. coli dan satu sumber air minum positif mengandung MDR E. coli. Oleh karena itu untuk mencegah masalah kesehatan yang lebih jauh, perlu dilakukan pemeriksaan berkala terhadap berbagai bakteri patogen yang ada di masyarakat.
\end{abstract}

Kata kunci: Multidrug resistance, E. coli, air minum, Tangerang *Poltekkes Kemenkes Banten 
Pendahuluan

Escherichia coli (E. coli) merupakan patogen yang paling sering menyebabkan infeksi nosokomial dan mudah menular dalam masyarakat [1, 2]. Dalam beberapa tahun terakhir telah ditemukan penyebaran E. coli yang menunjukkan resistensi terhadap antibiotik spektrum luas [1, 3, 4] di beberapa negara. Di Indonesia sendiri belum ada data meskipun setiap fasilitas kesehatan memiliki kewajiban untuk melakukan pemeriksaan minimal satu kali dalam setahun sesuai dengan kewaspadaan standar dalam Pencegahan dan Penularan Infeksi (PPI).

Timbulnya resistensi bakteri patogen terhadap berbagai antibiotik menjadi ancaman serius bagi kesehatan masyarakat karena akan semakin sedikit atau bahkan tidak ada lagi antibiotik yang efektif untuk pengobatan infeksi yang disebabkan oleh bakteri tersebut [1, 3-5]. Menurut European Centre for Disease Prevention and Control (ECDC) dan Centers for Disease Control and Prevention (CDC), multidrug resistant (MDR) didefinisikan sebagai ketidakrentanan terhadap paling sedikit satu antibiotik dalam tiga kelas antibiotik [6]. Bakteri MDR merupakan penyebab utama kegagalan pengobatan penyakit infeksi dan berdampak pada peningkatan morbiditas, mortalitas, dan tingginya biaya kesehatan $[7,8]$.

Multidrug resistant E. coli sering ditemukan di rumah sakit dan mulai banyak diisolasi di masyarakat sehingga perlu ditemukan antibiotik baru yang efektif [8-10]. Akan tetapi antibiotik golongan baru umumnya memiliki waktu afektif yang singkat [10] sehingga perlu dilakukan monitoring untuk mengetahui prevalensi MDR pada berbagai spesies termasuk E. coli [9, 11]. Berbagai kajian di Eropa [1] dan Amerika [4, 12] menemukan MDR pada isolat E. coli. Isolat bakteri yang berasal dari Asia dan Afrika umumnya memiliki rasio MDR yang tinggi [13, 14]. Di Indonesia masih sedikit data mengenai prevalensi MDR pada isolat spesies penting penyebab penyakit. Penelitian ini bertujuan untukmenentukan gambaran prevalensi dan kerentanan MDR E. coliyang diisolasi dari sumber air minum masyarakat yang 
berada di Kota Tangerang terhadap berbagai antibiotik.

Penelitian mengenai MDR mikroorganisme di Indonesia masih sangat sedikit. Tercatat mulai tahun 1996 hingga November 2015 hanya ada 23 publikasi internasional yang dapat ditemukan menggunakan perangkat lunak EndNote®. Sepuluh di antaranya mengenai Plasmodium [15], tujuh penelitian mengenai Tuberculosis [16], tiga mengenai Salmonella [17], satu Vibrio [18], satu fungi [19], satu lepra [20], dan belum ada penelitian mengenai MDR E. coli.

Berdasarkan latar belakang di atas, maka rumusan masalah dalam penelitian ini adalah bagaimana gambaran MDR E. coli yang diisolasi dari sumber air masyarakat yang berada di Kota Tangerang terhadap antibiotik dari lima golongan berbeda.

\section{Metode Penelitian}

Desain yang digunakan adalah penelitian eksperimental laboratorium. Populasi dalam penelitian ini adalah seluruh bakteri E. coli yang diisolasi dari sumber air minum masyarakat di Kota
Tangerang. Semua bakteri yang diisolasi digunakan sebagai sampel.

Pengambilan sampel dilakukan dengan cara air dimasukkan ke dalam botol steril sebanyak $100 \mathrm{ml}$ secara aseptis. Kemudian sampel ditempatkan dalam wadah botol dan dibawa ke Laboratorium Mikrobiologi Jurusan Analis Kesehatan Poltekkes Kemenkes Banten.

\section{Isolasi Escherichia coli}

Isolasi dan identifikasi Escherichia coli dilakukan berdasarkan metode Toshima [21], Janezic [22]. Sebanyak $10 \mathrm{~mL}$ masing-masing sampel air diinokulasikan kedalam tiga tabung media LB kemudiandiinkubasikan pada suhu $37^{\circ} \mathrm{C}$ selama 24 jam. Dengan menggunakan mikropipet sebanyak $100 \mu \mathrm{L}$ biakan dari LB ditanam pada media BGLBBdan diinkubasikan pada suhu $44{ }^{\circ} \mathrm{C}$ selama 24 jam. Dengan menggunakan ose steril biakan dari BGLBB ditanam pada media EMBA.

\section{Identifikasi Escherichia coli}

Koloni yang tumbuh dilakukan pemeriksaan makroskopis berupa 
koloni hijau metalik dan secara mikroskopis dengan teknik pewarnaan Gramberupa bakteri batang berwarna merah (batang Gram negatif).

\section{Uji Resistensi Antibiotik}

Uji kerentanan antibiotik isolat $E$. coli dilakukan pada media plat agar Muller-Hinton (Merck®) menggunakan metode difusi cakram KirbyBauer. Koloni positif E. Coli dari EMBA dibuat suspensi bakteri 0,5 McFarland. Sebanyak 100 $\mu \mathrm{L}$ suspensi dispread menggunakan batang drigalski pada media $\mathrm{MH}$ kemudian 5 cakram antibiotik diletakkan dengan dengan jarak seragam.Antibiotik yang digunakan berasal dari lima kelas antibiotik antara lain amikacin $(30 \mu \mathrm{g})$, ciprofloxacin $(5 \mu \mathrm{g}), \quad$ tetracycline $(30 \mu \mathrm{g}), \quad$ meropenem $(10 \mu \mathrm{g})$, fosfomycin $(50 \mu \mathrm{g})$. Koloni yang tumbuh dalam zona $<14 \mathrm{~mm}$ di sekitar cakram antibiotik setelah 24 jam inkubasi pada suhu $37^{\circ} \mathrm{C}$ dianggap sebagai hasil positif resisten terhadap antibiotik.

\section{Pengelolaan dan Analisis Data}

Data hasil penelitian disajikan secara deskriptifdalam bentuk tabel ataupun gambar.

\section{Hasil Dan Pembahasan}

Sampel air minum masyarakat diambil dari sumber air yang secara umum dapat diakses dan dimanfaatkan masyarakat untuk keperluan rumah tangga. Dari 16 titik sumber air minum di wilayah kota Tangerang, enam di antaranya positif mengandung cemaran bakteri E. coli setelah diperiksa menggunakan media dan kondisi spesifik pertumbuhan bakteri tersebut (Tabel 1)

Escherichia coli sebagai bakteri batang Gram negatif yang dapat memfermentasi laktosa pada suhu $40^{\circ} \mathrm{C}$, lebih sering menimbulkan penyakit infeksi pada hewan dan manusia dibandingkan bakteri air lainnya. Penggunaan air buangan yang telah diolah sebagai sumber air merupakan asal muasal reemergensi dan distribusi bakteri patogen termasuk E. coli. Bakteri ini merupakan penyebab utama infeksi saluran kemih dan gastrointestinal pada manusia selain berperan 
penting sebagai indikator indeks kontaminasi air dan makanan oleh bakteri koliform.

Dari keenam biakan E. coli yang diisolasidilakukan pemeriksaan mikroskopis dengan teknik pewarnaan Gram berupa bakteri batang berwarna merah (Gram negatif) seperti terlihat pada Gambar 1.

Tabel 1.

Hasil uji fermentasi laktosa oleh E.coli

\begin{tabular}{|c|c|c|c|c|c|c|c|c|}
\hline \multirow{2}{*}{ No. } & \multirow{2}{*}{ Sampel } & \multicolumn{3}{|c|}{ LB $37^{\circ} \mathrm{C}$} & \multicolumn{3}{|c|}{ BGLB $40^{\circ} \mathrm{C}$} & \multirow{2}{*}{$\begin{array}{c}\text { EMBA } \\
\mathbf{3 7}^{\circ} \mathbf{C}\end{array}$} \\
\hline & & 1 & 2 & 3 & 1 & 2 & 3 & \\
\hline 1. & Sampel 1 & - & - & - & - & - & - & - \\
\hline 2. & Sampel 2 & + & + & + & + & + & + & - \\
\hline 3. & Sampel 3 & + & + & + & + & + & - & + \\
\hline 4. & Sampel 4 & + & + & + & + & + & + & - \\
\hline 5. & Sampel 5 & + & + & + & + & + & + & - \\
\hline 6. & Sampel 6 & + & + & + & + & + & + & + \\
\hline 7. & Sampel 7 & + & + & + & + & + & - & + \\
\hline 8. & Sampel 8 & - & - & + & - & - & + & - \\
\hline 9. & Sampel 9 & + & + & + & + & + & + & - \\
\hline 10. & Sampel 10 & + & + & + & - & + & - & - \\
\hline 11. & Sampel 11 & + & + & + & + & + & + & - \\
\hline 12. & Sampel 12 & + & + & + & + & + & + & - \\
\hline 13. & Sampel 13 & + & + & + & + & + & - & + \\
\hline 14. & Sampel 14 & - & - & - & - & - & - & - \\
\hline 15. & Sampel 15 & + & + & + & + & + & + & + \\
\hline 16. & Sampel 16 & + & + & + & + & + & + & + \\
\hline
\end{tabular}




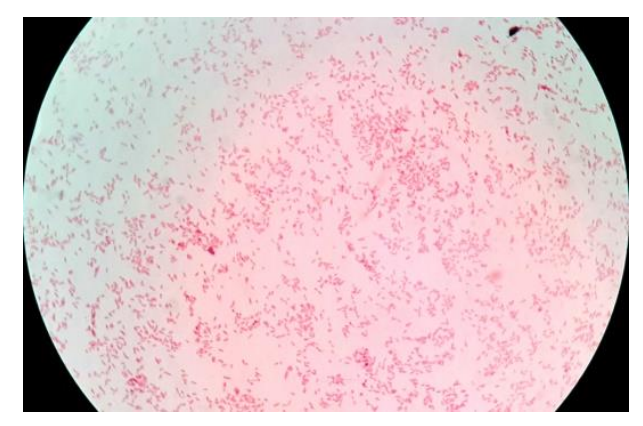

Gambar 1. Hasil pewarnaan Gram E. coli di bawah mikroskop, pembesaran 100x.

Uji kerentanan antibiotik isolat E. coli dilakukan pada media plat agar Muller-Hinton (Merck®) mengguna-kan metode difusi cakram Kirby-Bauer. Koloni positif E. Coli dari EMBA dibuat suspensi bakteri 0,5 McFarland. Sebanyak $100 \mu \mathrm{L}$ suspensi dispread menggunakan batang drigalski pada media $\mathrm{MH}$ kemudian 5 cakram antibiotik diletakkan dengan dengan jarak seragam.Antibiotik yang digunakan berasal dari lima kelas antibiotik antara lain amikacin $(30 \mu \mathrm{g})$, ciprofloxacin $(5 \mu \mathrm{g}), \quad$ tetracycline $(30 \mu \mathrm{g}), \quad$ meropenem $(10 \mu \mathrm{g})$, fosfomycin $(50 \mu \mathrm{g})$. Koloni yang tumbuh dalam zona $<14 \mathrm{~mm}$ di sekitar cakram antibiotik setelah 24 jam inkubasi pada suhu $37^{\circ} \mathrm{C}$ dianggap sebagai hasil positif resisten terhadap antibiotik. Tabel 1 menunjukkan hasil uji resistensi terhadap lima antibiotik.

Kemunculan resistensi antibiotik pada bakteri dalam masyarakat menandakan adanya masalah yang signifikan dalam bidang kesehatan [23, 24]. Menurut banyak penelitian, pewarisan fenomena resistensi antibiotik pada bakteri ditentukan oleh kromosom atau plasmid. Sel bakteri memiliki kemampuan untuk memindahkan gen secara horizontal yang dapat terjadi melalui tiga cara yaitu plasmid, fag, dan transformasi di mana bakteri menelan DNA bebas yang ada di dekatnya [25]. Plasmid sebagai DNA ekstra-kromosom secara independen dapat bereplikasi sendiri dan berperan penting dalam resistensi terhadap berbagai jenis antibiotik dan penyebaran gen resisten antibiotik [26]. Hal ini menimbulkan permasalahan serius karena plasmid dapat melintasi batas berbagai spesies dan genus sehingga memungkinkan resistensi menyebar dan persisten dalam organisme yang bukan subyek pemberian antibiotik [27]. 
Tabel 2.

Hasil uji resistensi $E$. coli terhadap lima antibiotik

\begin{tabular}{|l|l|c|c|c|c|c|c|}
\hline No. & Sampel & EMBA & AM & CIP & FOS & MEM & TET \\
\hline 1. & Sampel 3 & + & - & - & - & - & - \\
\hline 2. & Sampel 6 & + & - & - & - & - & + \\
\hline 3. & Sampel 7 & + & - & - & - & - & + \\
\hline 4. & Sampel 13 & + & - & + & - & - & + \\
\hline 5. & Sampel 15 & + & - & + & + & - & + \\
\hline 6. & Sampel 16 & + & - & - & - & - & - \\
\hline
\end{tabular}

Dalam penelitian ini kami menemukan E. coli yang resisten terhadap tetracycline. Sebuah studi menunjukkan tingginya prevalensi isolat E. coli resisten tetracycline pada daging sapi disebabkan oleh transfer gen resisten tetracycline antar dalam populasi E. coli yang berhasil bertahan terhadap cekaman selektif penggunaan antimikroba [28].

Selain tetracycline, kami juga menemukan E. coli yang resisten terhadap Ciprofloxacin yang merupakan antibiotik dari keluarga fluoroquinolon. Isolat E. coli ekstraintestinal yang resisten terhadap ciprofloxacin dapat ditemukan dalam sampel darah dan urin dari kasus septisemia yang terjadi di rumah sakit maupun masyarakat [29].
Fosfomycin adalah salah satu antibiotik oral dengan aktivitas sangat baik terhadap E. coli secara in vitro. Antibiotik ini mempunyai resistensi silang yang sangat rendah dengan antibiotik lain sehingga menjadi alternatif terbaik untuk pengobatan infeksi saluran kemih akibat E. coli penghasil ESBL [3032]. Fosfomycin tetap aktif terhadap E. coli [30] meskipun telah bertahuntahun digunakan di Eropa [33, 34] untuk pengobatan komplikasi infeksi saluran kemih. Namun di sini kami menemukan $E$. coli yang resisten terhadap fosfomycin seperti sebuah penelitian yang dilakukan di satu area kesehatan masyarakat di Madrid, Spanyol yang juga telah menemukan E. coli isolat urin yang resisten terhadap fosfomycindi tahun 2009 [35]. 


\section{Simpulan}

1. Sumber air minum masyarakat di Kota Tangerang ada yang tercemar E. coli.

2. Terdapat MDR E. coli di antara isolat yang diperoleh dari sumber air minum masyarakat di Kota Tangerang.

Oleh karena itu untuk mencegah masalah kesehatan yang lebih jauh, perlu dilakukan pemeriksaan berkala terhadap berbagai bakteri patogen yang ada di masyarakat.

\section{Daftar Pustaka}

1. Oteo, J., et al., Antimicrobialresistant invasive Escherichia coli, Spain. Emerg Infect Dis, 2005. 11(4): p. 546-53.

2. Drago, L., et al., In vitro selection of resistance in Escherichia coli and Klebsiella spp. at in vivo fluoroquinolone concentrations. BMC Microbiol, 2010. 10: p. 119.

3. Bartoloni, A., et al., Multidrugresistant commensal Escherichia coli in children, Peru and Bolivia. Emerg Infect Dis, 2006. 12(6): p. 907-13.

4. Sahm, D.F., et al., Multidrugresistant urinary tract isolates of Escherichia coli: prevalence and patient demographics in the United States in 2000. Antimicrob Agents Chemother, 2001. 45(5): p. 1402-6.
5. Liebana, E., et al., Public health risks of enterobacterial isolates producing extended-spectrum beta-lactamases or AmpC betalactamases in food and foodproducing animals: an EU perspective of epidemiology, analytical methods, risk factors, and control options. Clin Infect Dis, 2013. 56(7): p. 1030-7.

6. Magiorakos, A.P., et al., Multidrug-resistant, extensively drug-resistant and pandrugresistant bacteria: an international expert proposal for interim standard definitions for acquired resistance. Clin Microbiol Infect, 2012. 18(3): p. 268-81.

7. Howard, D.H., et al., The global impact of drug resistance. Clin Infect Dis, 2003. 36(Suppl 1): p. S4-10.

8. Coates, A., et al., The future challenges facing the development of new antimicrobial drugs. Nat Rev Drug Discov, 2002. 1(11): p. 895-910.

9. Peralta, G., et al., Impact of antibiotic resistance and of adequate empirical antibiotic treatment in the prognosis of patients with Escherichia coli bacteraemia. J Antimicrob Chemother, 2007. 60(4): p. 85563.

10. Rahman, S., et al., Antibacterial activity of natural spices on multiple drug resistant Escherichia coli isolated from drinking water, Bangladesh. 
Ann Clin Microbiol Antimicrob, 2011. 10: p. 10.

11. Guerra, B., et al., Phenotypic and genotypic characterization of antimicrobial resistance in Escherichia coli 0111 isolates. J Antimicrob Chemother, 2006. 57(6): p. 1210-4.

12. Boyd, L.B., et al., Increased fluoroquinolone resistance with time in Escherichia coli from $>17,000$ patients at a large county hospital as a function of culture site, age, sex, and location. BMC Infect Dis, 2008. 8: p. 4.

13. Kibret, M. and B. Abera, Antimicrobial susceptibility patterns of E. coli from clinical sources in northeast Ethiopia. Afr Health Sci, 2011. 11 Suppl 1: p. S40-5.

14. Kader, A.A. and A.K. Kumar, Prevalence of extended spectrum beta-lactamase among multidrug resistant gramnegative isolates from a general hospital in Saudi Arabia. Saudi Med J, 2004. 25(5): p. 570-4.

15. Poespoprodjo, J.R., et al., Dihydroartemisinin-piperaquine treatment of multidrug resistant falciparum and vivax malaria in pregnancy. PLoS One, 2014. 9(1): p. e84976.

16. Marwoto, et al., Correlation of Single Nucleotide Polymorphism 35-Kb Upstream of HLA-C and Clinical Profile of MultidrugResistant Tuberculosis. J Clin Diagn Res, 2015. 9(9): p. DC103.
17. Wong, V.K., et al., Phylogeographical analysis of the dominant multidrug-resistant H58 clade of Salmonella Typhi identifies inter- and intracontinental transmission events. Nat Genet, 2015. 47(6): p. 632-9.

18. Waturangi, D.E., et al., Edible ice in Jakarta, Indonesia, is contaminated with multidrugresistant Vibrio cholerae with virulence potential. $\mathrm{J}$ Med Microbiol, 2013. 62( $\mathrm{Pt} 3)$ : p. 352-9.

19. Pfaller, M.A., et al., Candida krusei, a multidrug-resistant opportunistic fungal pathogen: geographic and temporal trends from the ARTEMIS DISK Antifungal Surveillance Program, 2001 to 2005. J Clin Microbiol, 2008. 46(2): p. 51521.

20. Maeda, S., et al., Multidrug resistant Mycobacterium leprae from patients with leprosy. Antimicrob Agents Chemother, 2001. 45(12): p. 3635-9.

21. Toshima, H., et al., Detection and isolation of Escherichia coli with a coding gene for enteroaggregative Escherichia coli heat-stable enterotoxin 1 from food and comparison with fecal isolates. J Food Prot, 2004. 67(10): p. 2117-22.

22. Janezic, K.J., et al., Phenotypic and Genotypic Characterization of Escherichia coli Isolated from Untreated Surface Waters. Open Microbiol J, 2013. 7: p. 9-19. 
23. Baquero, F. and J. Blazquez, Evolution of antibiotic resistance. Trends Ecol Evol, 1997. 12(12): p. 482-7.

24. Lipsitch, M. and M.H. Samore, Antimicrobial use and antimicrobial resistance: a population perspective. Emerg Infect Dis, 2002. 8(4): p. 347-54.

25. Thomas, C.M. and K.M. Nielsen, Mechanisms of, and barriers to, horizontal gene transfer between bacteria. Nat Rev Microbiol, 2005. 3(9): p. 711-21.

26. Furuya, E.Y. and F.D. Lowy, Antimicrobial-resistant bacteria in the community setting. Nat Rev Microbiol, 2006. 4(1): p. 36-45.

27. Hughes, V.M. and N. Datta, Conjugative plasmids in bacteria of the 'pre-antibiotic' era. Nature, 1983. 302(5910): p. 725-6.

28. Shin, S.W., et al., Prevalence of Antimicrobial Resistance and Transfer of Tetracycline Resistance Genes in Escherichia coli Isolates from Beef Cattle. Appl Environ Microbiol, 2015. 81(16): p. 5560-6.

29. Cerquetti, M., et al., Ciprofloxacin-resistant, CTX-M15-producing Escherichia coli ST131 clone in extraintestinal infections in Italy. Clin Microbiol Infect, 2010. 16(10): p. $1555-8$.

30. Falagas, M.E., et al., Fosfomycin for the treatment of multidrug- resistant, including extendedspectrum beta-lactamase producing, Enterobacteriaceae infections: a systematic review. Lancet Infect Dis, 2010. 10(1): p. 43-50.

31. Oteo, J., et al., Parallel increase in community use of fosfomycin and resistance to fosfomycin in extended-spectrum betalactamase (ESBL)-producing Escherichia coli. J Antimicrob Chemother, 2010. 65(11): p. 2459-63.

32. Falagas, M.E., et al., Fosfomycin versus other antibiotics for the treatment of cystitis: a metaanalysis of randomized controlled trials. J Antimicrob Chemother, 2010. 65(9): p. 1862-77.

33. Galatti, L., et al., Antibiotic prescribing for acute and recurrent cystitis in primary care: a 4 year descriptive study. J Antimicrob Chemother, 2006. 57(3): p. 551-6.

34. Knottnerus, B.J., et al., Fosfomycin tromethamine as second agent for the treatment of acute, uncomplicated urinary tract infections in adult female patients in The Netherlands? J Antimicrob Chemother, 2008. 62(2): p. 356-9.

35. Oteo, J., et al., CTX-M-15producing urinary Escherichia coli O25b-ST131-phylogroup B2 has acquired resistance to fosfomycin. J Antimicrob Chemother, 2009. 64(4): p. 7127. 
